DIGITAL COMMONS
@ UNIVERSITY OF SOUTH FLORIDA

Volume 4

Issue 1 Volume 4.1 (Spring 2014)

\section{ABO: Interactive Journal for Women in the Arts, 1640-1830}

2014

\title{
The Secret Life of Archives: Sally Siddons, Sir Thomas Lawrence, and The Material of Memory
}

Laura Engel

Duquesne University, Pittsburgh, engell784@duq.edu

Follow this and additional works at: https://digitalcommons.usf.edu/abo

Part of the Dramatic Literature, Criticism and Theory Commons, Educational Methods Commons, Feminist, Gender, and Sexuality Studies Commons, and the Literature in English, British Isles Commons

\section{Recommended Citation}

Engel, Laura (2014) "The Secret Life of Archives: Sally Siddons, Sir Thomas Lawrence, and The Material of Memory," ABO: Interactive Journal for Women in the Arts, 1640-1830: Vol.4: Iss.1, Article 2.

http://dx.doi.org/10.5038/2157-7129.4.1.1

Available at: https://digitalcommons.usf.edu/abo/vol4/iss1/2

This Scholarship is brought to you for free and open access by Digital Commons @ University of South Florida. It has been accepted for inclusion in ABO: Interactive Journal for Women in the Arts, 1640-1830 by an authorized administrator of Digital Commons @ University of South Florida. For more information, please contact digitalcommons@usf.edu. 


\title{
The Secret Life of Archives: Sally Siddons, Sir Thomas Lawrence, and The Material of Memory
}

\begin{abstract}
This essay is in two parts, in the first I attempt to map out strategies for considering archival materials through the lens of performance, and in the second I enact or perform some of those strategies through a close reading of a letter from Sally Siddons, daughter of the famous actress Sarah Siddons, to the renown portrait painter and rakish bad boy, Sir Thomas Lawrence. I present a methodology that considers archival researchers as tourists who approach archival objects and images as material for curating a virtual exhibition. I argue that this strategy allows us to recognize and attempt to envision the interdisciplinary relationship amongst archival materials in order to imagine them in spatial, theatrical, and visual proximity to one another. In this way as researchers we are performing a kind of re-enactment, an animation, of the secret life of archives, which attempts to account the embodied traces of the past by providing an accessible thought provoking map for audiences.
\end{abstract}

\section{Keywords}

theater history, actresses, performance, archives, sarah siddons, sir thomas lawrence, material culture, feminist theory

\section{Creative Commons License}

(c) $($ ) $\Theta$

This work is licensed under a Creative Commons Attribution-No Derivative Works 3.0 License. 


\section{Part one: the archival tourist and the secret life of archives}

In a $2011 P M L A$ issue devoted to the emerging field of celebrity studies the father of the discipline, Leo Braudy, offered some thoughts about potential strategies for research in this new field:

Fame and celebrity studies ideally also concentrate on the extra-textual aspect of performance, all the 'surround' of the performer ... [or] everything else that the audience pays attention to ... [ [which] includes the material culture of books, visual images, and previous performances, as well as the more immaterial culture of gossip, personal psychological inclinations, and inchoate cultural attitudes. (1073)

Braudy's concept of the extra-textual and often intangible "surround" is important to researchers in celebrity studies but also to investigations of the past in general. Part of the process of re-animating or re-imagining narratives surrounding fame, celebrity, and reputation is that these stories are connected to embodied histories-which are often, if not always, ephemeral, fragmented, and ghostly, particularly in relation to women.

A recent shift in the field of theater history towards the study of actresses and women in the theater has brought new attention to the question of how to document the fascinating and often elusive lives of eighteenth-century female performers. ${ }^{1}$ As Felicity Nussbaum has recently pointed out in her book Rival Queens, focusing on actresses, performers who actually lived, shifts questions about the creation of female subjectivities from Catherine Gallagher's famous "fictional nobodies" to "real" embodied somebodies. Nussbaum writes: "The fictional nobodies that Catherine Gallagher found in the novel became theatrical somebodies when they mounted the stage as dramatic characters; actresses trading on their acting reputations represented quite the opposite of the disembodied female author who often veiled her public identity, appearing as a nameless, anonymous being" (18). Yet, even though the study of actresses is based on the premise of real live bodies, how do we find evidence of these bodies and their lived experience in the archives? How do we access and then document what Braudy terms the "surround"? And, how do we extend these practices to research on other subjects: to authors, playwrights, musicians, letter writers, and "ordinary" people? Is there a feminist methodology for archival research? How has the recent turn to digitization of the archive and virtual archive projects affected our ability to investigate, document, and re-imagine the past? In this essay, I'd like to offer some thoughts in progress about these questions, as well as providing a preliminary model for a methodology for archival research that considers archival objects as well as the practices of the archival researcher through the dynamics of performance. ${ }^{2}$

According to Jacques Derrida, "nothing is less clear today than the word "archive"" (qtd. in Manoff: 10). For some scholars and practitioners the archive refers to a physical site a museum, a library, or a registry office that houses an archive or a collection of materials. For others the archive is a less tangible concept that encompasses everything that exists in the digital environment, still others use the term "archive" to describe a theoretical 
overlapping of discourses that represent and produce power, knowledge, and various technologies of meaning making. ${ }^{3}$

\section{$\underline{\text { http://libraries.cca.edu/archives/item-detail.php?work-id=945 }}$}

The image here is an archival photograph from a women's art class at the California College of Art at the turn of the century. It's a fascinating photograph because it is an archival record of so many things at once-the theater of the classroom, modeling practices, the gaze between artist and subject, all of which encompass a variety of layered ideologies about representation and gender. Postmodern archival theorists see the archive as a center of interpretation, a non-objective, non-neutral collection of materials to be read and analyzed. The archive is also a site of collective and individual memories that often produce a larger cultural narrative with a specific political and/or national agenda. The archive both records events and produces them. Although archival theory has become difficult to define, scholars like Carolyn Steedman remind us of the importance of archives as real spaces with actual things in them. According to Steedman, the archive is not a metaphor re: Derrida and Foucault, it is a literal and concrete space and old books are "the very stuff of the scholar's life" (qtd. in Manoff: 17).

I am particularly interested in a specific branch of archival studies that connects archival research with theories and practices of performance and performance studies. The work of Diana Taylor, Joseph Roach, Greg Dening, Gilli Bush Bailey, Heather Davis-Fisch and others is concerned specifically with how to account for Leo Braudy's "surround." In her brilliant book The Archive and the Repertoire, Diana Taylor distinguishes between the archive as a set of tangible documents and objects, and the repertoire which consists of ephemeral intangible information: dance, ritual, behavior and gestures that often go unrecorded and are difficult to document in official or institutional ways. Joseph Roach has mapped the elusive history of "it" ness by tracing the "flesh and blood" details of "synthetic experience" in Pepys's diary and funeral effigies of King Charles the II. Roach also examines portraits, accessories, figurines, and other ephemera associated with celebrities then and now. Greg Dening's "ethnographic history" similarly considers the ways in which archival materials contain traces of the past, which are then re-interpreted by historians in the present. For Dening, "The relics of the past, the only ways in which the past survives, are cargo to all the present moments that follow . . . . They are marked with the meanings of the occasion of their origins and they are always translated into something else for the moments they survive. Historical consciousness is always built out of that double meaning" (qtd. in Davis-Fisch: 14-15). Each of these theorists is dealing in particular ways with the central dilemma Heather Davis-Fisch's recent study Loss and Cultural Remains in Performance articulates: "How can one locate and recuperate the repertoire - the embodied performances of the past—in and from the archive?" (16).

To complicate matters further, if we are interested in recuperating the embodied performances of the past from material in the archive, how do we also take into account the embodied performances of the present - or put another way, the performances of the archivist and/or the scholar performing archival research. Terry Cook and Joan Schwartz propose: archives "“are not passive storehouses of old stuff, but active sites where social 
power is negotiated, contested, confirmed.' By extension, memory is not something found or collected in archives, but something that is made, and continually re-made" (172). Archivists are thus "performers in the drama of memory making" (172). Invoking Judith Butler they argue: "Postmodernism requires archivists to accept their own historicity, to recognize their own role in the process of creating archives and to reveal their own biases" (182). For Cook and Schwartz once we acknowledge archival practice as a form of performance, we will be better able to become, what they call, "performance conscious" (185).

One way to begin to become "performance conscious" is to think about the archival researcher as a kind of tourist. As Scott Lash explains "we are tourists much of the time whether we like it or not" (qtd. in Endsor: 61) . . John urry adds"we can be tourists in our everyday travels, whether actual or virtual" (61). I want to propose some important connections between archival researchers and tourists. Like archival scholars, tourists are always audience members and actors at the same time. Tourists' experiences are characterized by embodied involvement, transaction, or confrontation with a foreign other, and by witnessing an often-staged body of materials to be interpreted and translated. Thinking about archival research as a form of tourism reminds us that there is a boundary between the materials of the past and the desires of the present, at the same time that the idea of tourism acknowledges a willingness to enter into particular scenarios and narratives. Many popular tourist sites involve historical re-enactment and simulation. For example, in the eighteenth-century cotton mill, Quarry Bank, in Cheshire: "A team of museum interpreters bring the house to life. Dressed in costume, they engage visitors in conversation ... often in-role as one of the real characters who lived at the house. ... Visitors are encouraged to touch all the objects; test the straw filled beds, stir the porridge in the kitchen, and pump water from the well in the yard" (qtd. in Endsor: 66).

\section{http://media-cdn.tripadvisor.com/media/photo-s/03/9d/82/6d/quarry-bank-mill.jpg}

Theater historian Gilli Bush-Bailey connects the idea of heritage tours and historical reenactments to the study of theater history. She explains: "The desire to 'know' about one's own past, the individualised genealogical quest for a personal family history, has elided with a public desire for a shared cultural memory, both coming together to satisfy what cultural historians recognise as a "yearning to experience history somatically and emotionally - to know what it felt like" (281). She adds: "As visitors or audiences in the theater yard or gallery, we are, in effect, re-enactors" (288). An interesting example of the crossing between tourist and academic re-enactment is our current cultural fascination with all things Jane Austen and with the ways in which Austen's past resurfaces continuously in our present, thanks in part to a thriving Austen tourist industry and to JASNA (The Jane Austen Society of North America).

But I want to make a distinction between tourists dressing in costume and what I mean by archivists as tourists. I'm very struck by Gilli Bush-Bailey's observation that "Professional historians are also entering into re-enactment, becoming re-enactors in their 
own archival projects" (282). Bailey herself has written a one-act play about the actress Fanny Kelly, whom she has also written an academic book about. Through this reenactment Bailey is consciously attempting to work out the performative bridges between the past and the present. In other words her project is concerned with acknowledging the embodied traces of the past through her own embodied activities. She explains: "Theatre historians should acknowledge what we know but often leave to be realised by others: that text may be embodied and that, without the body, theater is only a place of the imagination" (296).

Following Bailey's call to bring the theater and the body back into archival research I propose a methodology for archival research that views archival materials through the lens of performance, keeping in mind the language of props, staging, embodied presence, and desire - in other words, I want to imagine the Archive in 3-D. Griselda Pollock's concept of the Virtual Feminist Museum, a virtual exhibition of juxtaposed images, is helpful in thinking about what I am outlining here. Pollock reminds us that "The archive is selective not comprehensive. It is pre-selected in ways that reflect what each culture considered worth storing and remembering .... Vast areas of social life and huge numbers of people hardly exist, according to the archive. The archive is over determined by facts of class, race, gender, and above all power" (12). Pollock proposes the concept of the Virtual Feminist Museum to challenge these ideologies. She explains that The Virtual Feminist museum is not like the modernist museum, which is about "mastery, classification, [and] definition" (11). It is instead "about argued responses, grounded speculations, exploratory relations, that tell us new things about femininity, modernity, and representation" (11).

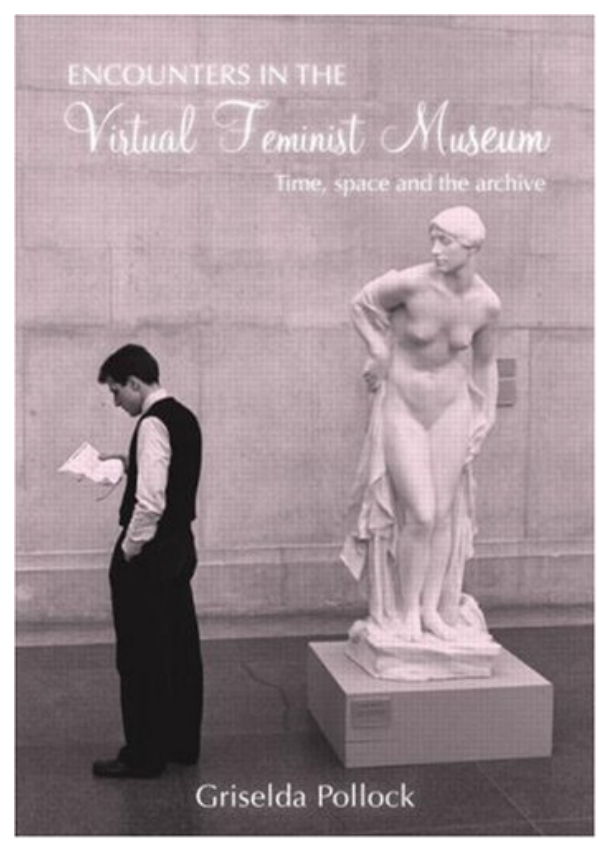

Thus, I suggest that as archival tourists we consider archival materials as if we were curating a virtual exhibition-that we recognize and attempt to envision the interdisciplinary relationship amongst archival materials in order to imagine them in spatial, theatrical, and visual proximity to one another. In this way as researchers we are 
performing a kind of re-enactment-an animation, if you will, of the secret life of archives, which attempts to account for the "surround" and the embodied traces of the past by providing an accessible thought provoking map for audiences. For all performances require audiences. Thomas Osborne explains:

The person who speaks from the archive is the person who mediates between the secrets or obscurities of the archive and some or other kind of public. To be sure, if the existence of an archive always presumes an the existence of a public ... the reader of the archives, re-animates the discourses he or she discovers in the archives, giving them an aura of a certain rarity, a kind of extraordinary ordinariness. $(54,62)$

The reader of the archives is responsible, then, for conjuring the "secret life" or the "extra-textual surround" of archival materials, a process that requires thinking about these materials as part of a larger network of objects, images, and bodies. Imagining these networks by curating "virtual exhibitions," (by thoughtfully and deliberately juxtaposing images and envisioning materials in spacial/ theatrical dimensions), can evoke what I call "spectral matter"-in other words what is echoed by the archival object itself but remains invisible and unseen. ${ }^{4}$

To sum up the process I have been imagining, here is a working schema for thinking through what I am calling "the secret life of archives":

1. Archival objects (letters, diaries, photographs, clothing, pictures, jewelry etc.) conjure the specific scene(s) in which they once existed; they are inextricably linked to embodied performances which are now lost. In addition to conjuring visible aspects of particular scenes, archival objects also echo intangible acts that leave no visible trace.

2. Curating a "virtual exhibition" of related archival objects by juxtaposing images and considering them in relation to one another can produce a sense of the "spectral matter" of the scene, of the invisible aspects of the scene that can be felt but not seen such as desire, vulnerability, and loss, as well as the performances surrounding the scene as it happened-in other words what remains hidden off stage.

3. Engaging in archival research that considers materials through the lens of performance is related to the experience of tourism, where an individual immerses herself in a foreign environment, relating to and analyzing visual and sensory materials through embodiment and enactment. The archival tourist is part of the scene of research and has agency in the recreation of the past, at the same time that the archivist remains separated from the materials because they are always ultimately foreign.

In the second part of this essay I am going to do a brief enactment of the process I outline above using a love letter written by Sally Siddons, daughter of the famous actress, Sarah Siddons, to the portrait painter Sir Thomas Lawrence. 
"Portrait of Sarah Martha (Sally) Siddons" (1775-1803), Sir Thomas Lawrence. http://www.christies.com/lotfinderimages/D55205/sir_thomas_lawrence_pra_portrait_of_ sarah_martha_siddons_daughter_of_s_d5520541h.jpg

\section{Part two: Sally Siddons, Sir Thomas Lawrence and the material of memory}

A series of letters housed in the Cambridge Library and published in 1905 in a volume entitled An Artist's Love Story edited by Oswald Knapp, tell the tale of a doomed love triangle between the celebrated artist Sir Thomas Lawrence and both of the famous actress Sarah Siddons' daughters-Sally and Maria. Lawrence first attracted the attention of Siddons's daughters, who had been away at school in Calais, when he visited the family frequently in 1797 while painting Sarah Siddons' portrait. Lawrence initially began a secret courtship with Siddons' daughter Sally. But, in a strange twist of events, in 1798 he became engaged to Maria, who knowing that she was very ill, announced to her mother that she would not survive if she were not allowed to marry Lawrence. Sarah Siddons agreed to the engagement, but Lawrence decided that he wasn't in love with Maria, but rather with Sally. After Maria's death, Sally refused to see Lawrence and he began to stalk her while she was on tour with her mother. Eventually Lawrence lost interest in their relationship. Sally continued to love him until her death in 1803 at the age of 24 .

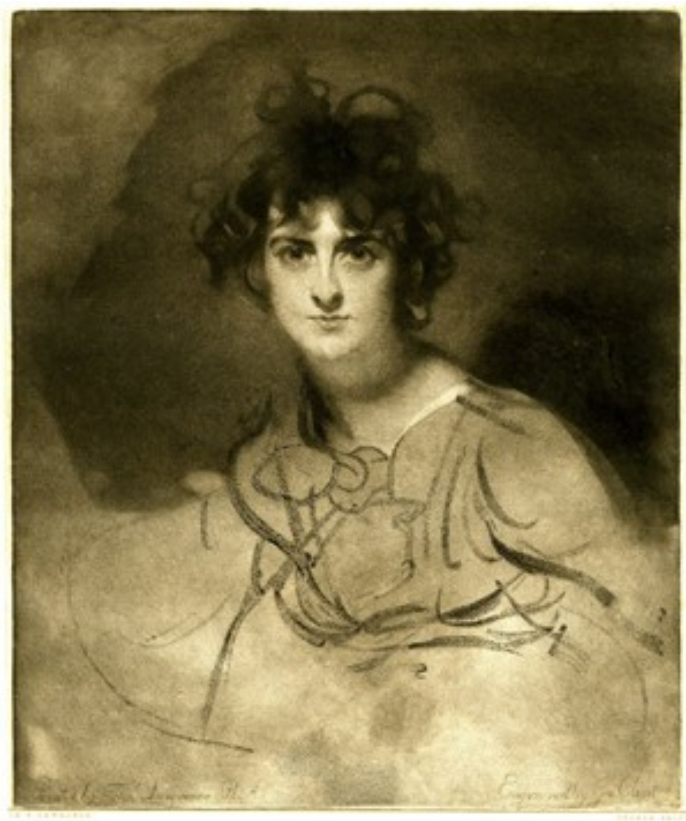

"Portrait of Miss Maria Siddons," Sir Thomas Lawrence. @ $\odot$ The Trustees of the British Museum

Reading these letters in sequence is very much like the experience of reading an eighteenth-century epistolary novel. All the ingredients of a great sentimental narrative are here-love, passion, betrayal, heartbreak, and death. The letters are, in fact, sprinkled with literary allusions to authors including: Shakespeare, Rousseau, Richardson, Sheridan, 
and Lewis. The primary heroine of the letters is actually not Sarah Siddons, but Sally Siddons, an accomplished musician and composer who drew inspiration for her musical compositions from literary sources.

An extraordinary letter from Sally Siddons to Lawrence introduces an array of material artifacts that help to contextualize, reenact, and embody the relationship between them. ${ }^{5}$ In the letter, Sally describes two significant pieces of jewelry: a ring in the design of a lover's knot that she has purchased for Lawrence and given to him secretly at a chance meeting at the theater, and a locket containing strands of hair from Lawrence and her mother, which he apparently commented on during this clandestine encounter. In addition to the ring and the locket, the letter also helps to contextualize other material artifacts produced by their relationship, including a drawing of Sally done by Lawrence where she is represented wearing a locket and Shakespeare prints that they may have looked at together perhaps from John Boydell's Shakespeare Gallery. ${ }^{6}$

What I would like to do in the remaining part of this essay is to begin to think about these objects through the language of theatre and performance in order to re-invest these artifacts with the uncanny traces of embodiment that are best conveyed in terms of imaging the effect on the audience of actors and props on stage. In other words, if we consider the past to be a series of performances and letters to be narrative reenactments of those performances, then we can also begin to theorize the ways in which material artifacts like rings and lockets can function as props that connect bodies on stage and reveal specific information about the relationships between characters. Drawings can be useful in thinking about the ways in which the sitter's body appears in various costumes in specifically staged settings, and prints can help us to imagine how trajectories of desire can be mapped through attention to the proximity of bodies or the staging of bodies on the page and off. Through these moments, I want to propose a larger argument, which I have been sketching out, about the idea of embodied presence in the archives and the possibilities of gaining access to what Joseph Roach has famously called "the invisible performances of every day life." Connecting the archive with performance, to imagine the archive in 3-D, allows for the archive to represent more than the materials present in the box, and potentially makes a space for beginning to map out or imagine the intangible performances surrounding historical materials. This is a particularly useful strategy for dealing with archival materials by or about eighteenth and nineteenth-century women, whose unconventional lives and experiences often went unrecorded, or when written down became manipulated and distorted in an effort to re-imagine their unique position within accepted narratives of femininity.

The letter is dated Tuesday Morning 12'Oclock, 24th April 1798, during the period when Lawrence had reversed his attentions again and decided that he was not in love with Maria Siddons, but still with Sally, his original choice. Sally describes her feelings towards Lawrence after catching a glimpse of him at the theater, "And did I indeed see you, speak to you, last night? Good heavens! was it not rather a dream? No, no, it was reality. How short, how cruelly short, did the time appear! It seem'd to me that I had a thousandthings to say to you, and yet, I think I said nothing. But was it necessary to say? Oh! could you not read in my eyes the ecstasy of my heart?" (Goldring 140). Sounding 
very much like an actress in the throes of a dramatic monologue (something that she had witnessed countless times when her mother, Sarah Siddons performed), Sally invites us to imagine a scene of their chance meeting which was marked not by what was said, but by what was not said, yet implied through facial expression, gesture, and bodily movement - in other words through performance. Sally asks Lawrence to literally read her body, and she continues to elaborate on this practice throughout the letter by specifically referring to her body through the use of visual objects and imaginative staging.

Sally invokes the setting of the theater, a place of acting, gazing, and desire, which in the late eighteenth century represented the blurred boundaries between public and private spaces, and the presence of a variety of bodies from diverse classes in close proximity to one another. She writes: "I looked for you all over the pit last night, and had almost despair' $d$ of seeing you; but I found you out before you saw me. You were on both sides up one pair of stairs; then in the stage-box, where I believe Mr. Lysons pointed me out." (Goldring 140). Sally describes following Lawrence's body with her gaze until he spots her, then she imagines their future meeting together where they will walk in Soho square before breakfast. She then re-plays and restages the scenes she acted with Lawrence in the past; she imagines Lawrence's embodied presence through his absence. "Tell me-do you think of Sally? I sit where you have sat; I stand where you have stood; I look round on those Shakespeare prints, I try to recollect your observations on them. And which do I look on longest, most intently? Orlando-ddear Orlando! And then I write. Would you know what? You shall read'(140-141).

Although I can't say with certainty that the prints Sally and Lawrence were looking at were prints from John Boydell's Shakespeare Gallery, I'm going to show you two images from the As You Like it series in order to possibly imagine what they might have been gazing at intently together. The line that Sally quotes is possibly from Act V, Scene II, where Rosalind declares:

ROSALIND. O, my dear Orlando, how it grieves me to see thee wear thy heart in a scarf!

ORLANDO. It is my arm.

ROSALIND. I thought thy heart had been wounded with the claws of a lion.

Orlando: Wounded it is, but with the eyes of a Lady. (5.2.19-24)

Rosalind is still dressed as a man here - but about to subsequently reveal herself as a woman. The scene is about embodiment and desire and the complicated and mixed up signifiers of bodies, body parts and gender. Sally's provocative potential references to these charged images, one that stages a marriage about to be consummated, and the other that features Oliver's nearly naked body lying suggestively on the ground, conjure a scene of desire between herself and Lawrence and their collective gazing. We can only imagine what each of them might have been "looking on the longest."

As You Like It,” Act V Scene IV, William Hamilton, Boydell Shakespeare Gallery. 
http://s3.amazonaws.com/magnoliasoft.imageweb/bridgeman/fullsize/kw323349.jpg

"As You Like It," Act IV Scene III, Raphael Lamar West, Boydell Shakespeare Gallery. http://s3.amazonaws.com/magnoliasoft.imageweb/bridgeman/fullsize/kw323347.jpg

At this point in the letter Sally emphasizes the embodied practices of writing and reading. She underscores the process "and then I write" and "you shall read" suggesting a powerful connection between the act of writing words on paper, their visual impact on the page, and the transfer of that impact bodily onto the recipient of the letter. In the same way, perhaps, as an actress might mold her performance in order to inspire a specific embodied response from the audience, Sally Siddons enacts a similar strategy through visual, narrative, and theatrical representations. Heightening the suspense of the narrative Sally tells Lawrence that she no longer dares to write in her journal, since she is "forbid to express the feelings of my heart in my own words" (Goldring 141), yet in the form of the letter she is able to pointedly describe her desires and actions "This is what you shall read" she repeats (141).

In the climactic section of the letter Sally describes two pieces of jewelry that literally and figuratively tie her body to Lawrence's. She explains that she has bought him a ring in the shape of a "True Lover's Knot," which she secretly gives to him at the their chance meeting at the theater. "I bought it for you. I have worn it, kissed it, and waited anxiously for an opportunity to give it to you. Last night, beyond my hopes, it presented itself. You have it, keep it, love it, nor ever part with it till you return me my letters" (Goldring 141).

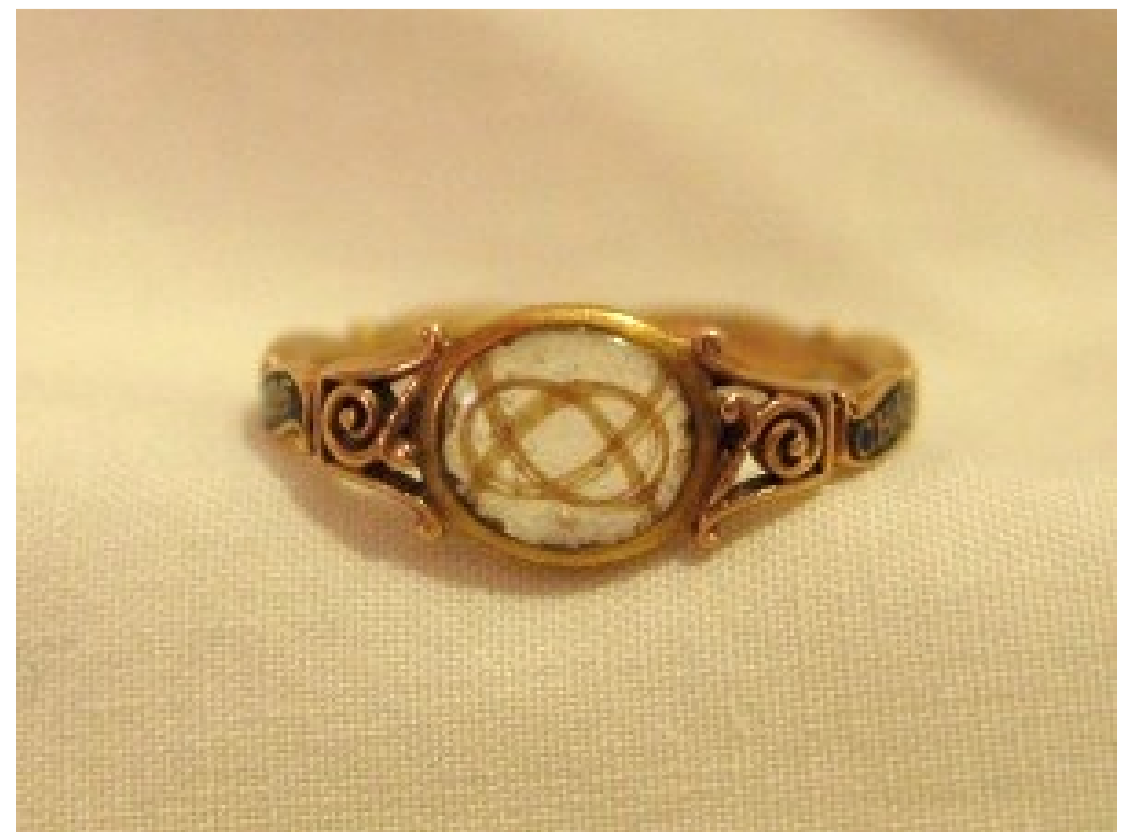

Eternity Twist Ring, Eighteenth Century. http://artofmourning.com/2011/12/16/4120/

Sally's detailed reenactment of her handling of the ring is a clear substitute for Lawrence himself. Rings function here as complex props both on and off stage because of the real 
and imagined relationships that they signify. In purchasing and then giving Lawrence a ring, Sally Siddons is in effect promising her body to Lawrence, and handing over a part of herself. Interestingly, she goes on in the letter to describe a locket that she wears always that contains a part of Lawrence's body: "You like my locket. Your hair and my mother's are in it - think if I prize it! I wear it always" (141). The locket that Sally refers to is a tangible material object that she associates with her love for both Lawrence and her mother - she keeps strands of both of their hair in it - a fetishistic representation of the power of their presence in her life. ${ }^{7}$

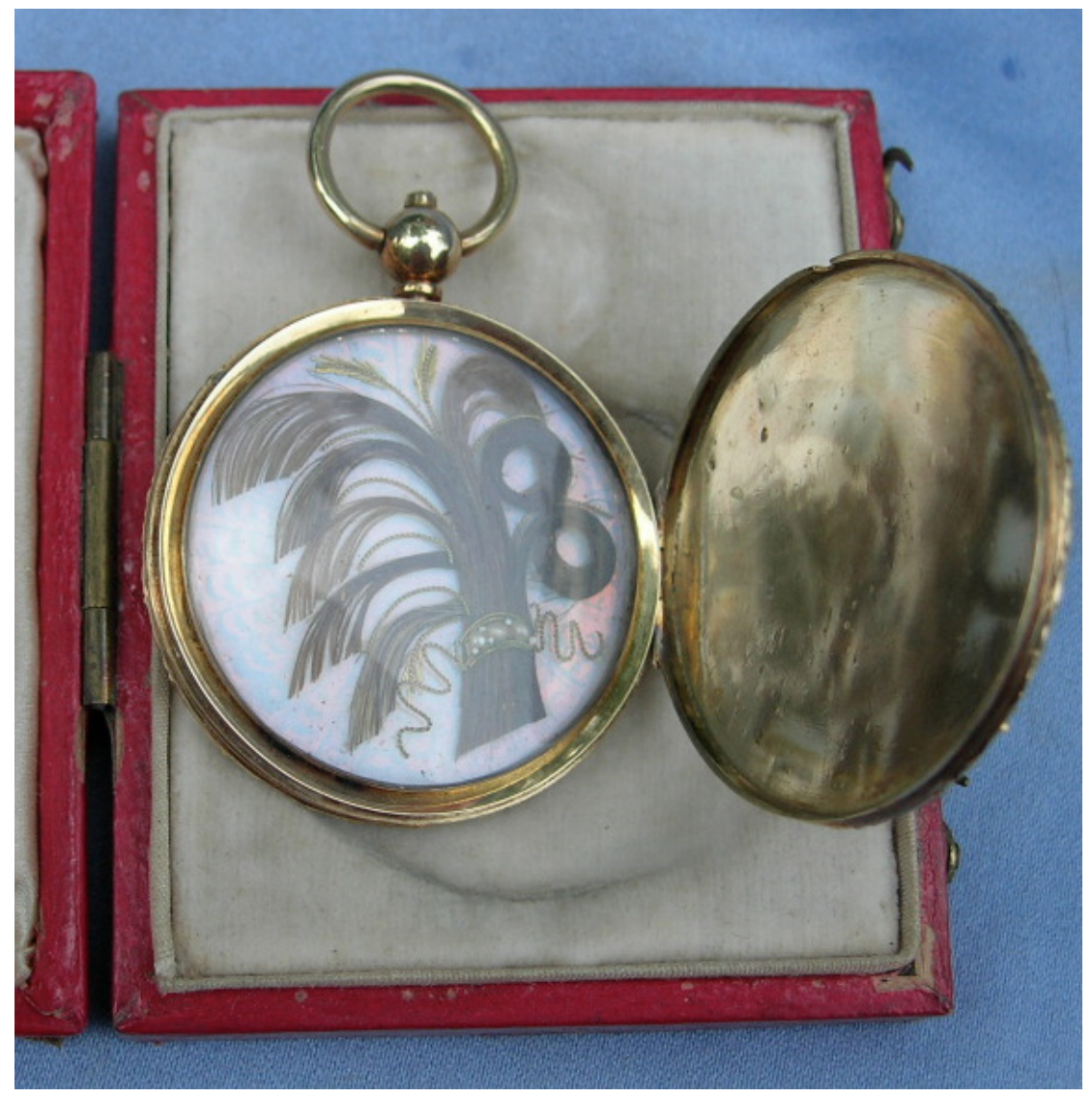

Family Hairwork Locket, c.1830. http://artofmourning.com/2013/02/13/family-hairworklocket-c-1830/

In Brilliant Effects: A Cultural History of Gem Stones and Jewellery, Marcia Pointon argues, "Hair in jewellery, I suggest, is characterized by paradoxical properties; in synecdochic relationship to the body, it stages the death of its subject and simultaneously (as a bodily substance that outlives the body) instantiates continuity and acts as a material figure for memory" (310). According to Pointon it was not unusual for hair jewelry to be invested in either erotic and/or memorializing discourses. She writes:

Discourses of looking around miniature objects therefore marked the intersection of the private and intimate with the social and public; they brought together men and women, children and parents, producing a space 
where excesses of emotion were permitted and articulated whether in mourning for a death or in contemplating absence of a different kind. These artefacts are not abstract but tangible and were understood to bring into tactile proximity the loved one - hence their range of application from the erotic to the memorializing. (298)

Sally's attention to her locket in her letter draws upon discourses of looking; she invites Lawrence to imagine her locket and by extension her body. While Pointon's comments here pertain directly to Sally's locket and her fantasies about her fraught relationship with Lawrence and her mother, Pointon's suggestions about hair in jewellery are also applicable to archival materials like letters. Sally's letters in particular, especially the ones in which she details her feelings of passion, betrayal, longing, and grief, operate in a "synecdochic relationship" to her body and literally and figuratively "stage the death" of her subjects. Letters, lockets, and rings are "material figures" of memory.

When I read Sally's description of her locket, I was determined to find an image of her wearing one. This drawing of Sally by Lawrence is dated 1797, well before this letter was written, most likely during their initial courtship before Lawrence had transferred his affections to Maria. 


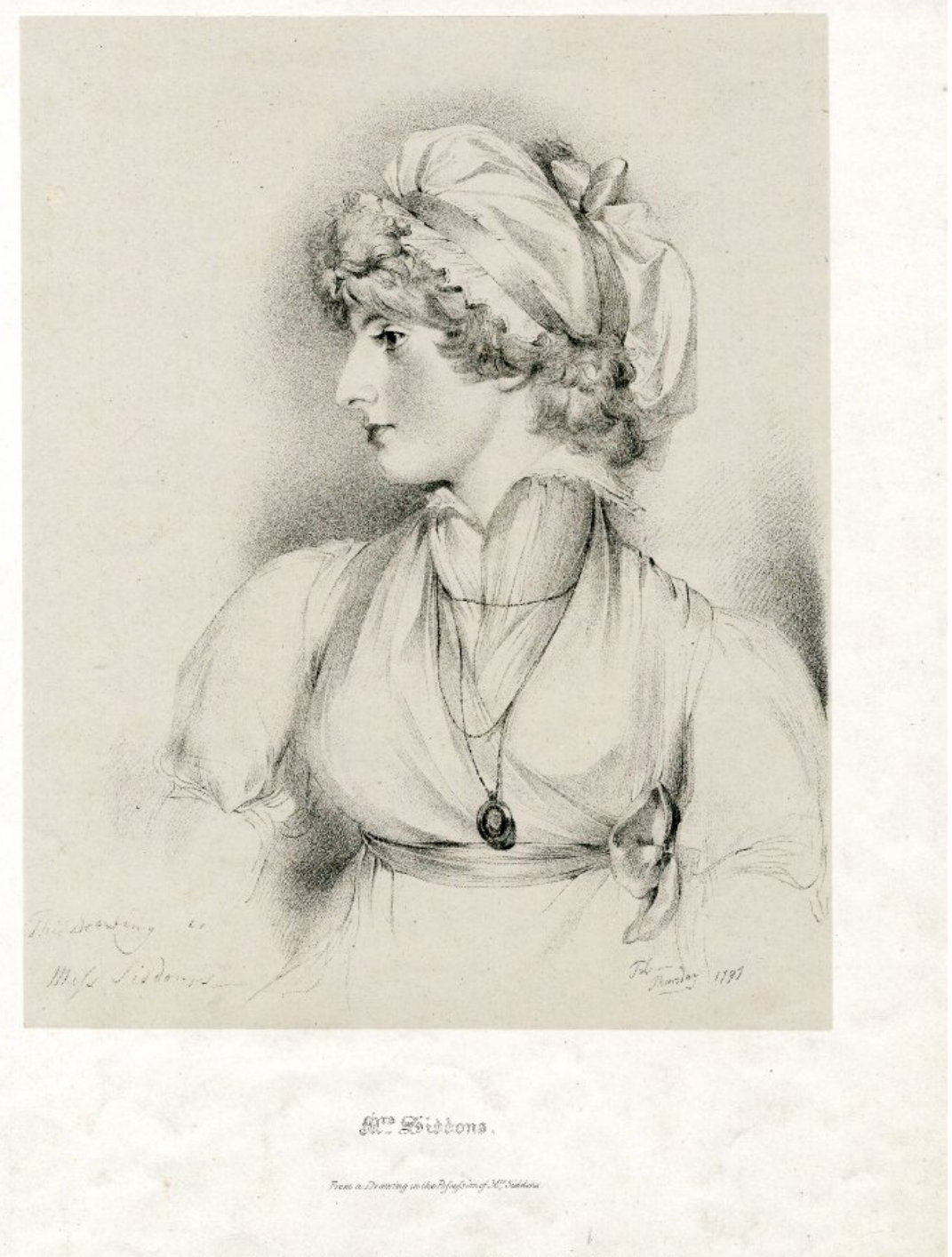

Portrait of Miss Sarah Martha (Sally) Siddons after a drawing by Sir Thomas Lawrence, 1797. () The Trustees of the British Museum.

In her excellent essay about Lawrence's representations of women, Art Historian Cassandra Albinson argues that his drawings, both the sketches that he did on canvas before painting and his studies on paper, function as "an invisible or shadow memento of the first encounter between artist and sitter" (31-32). Unlike his finished portraits of women, which represent them as fully costumed and staged subjects; Lawrence's drawings then can be seen as more intimate versions of his sitters. This drawing of Sally, which she indirectly refers to in her letter by focusing Lawrence's attention onto her locket, replays the emotionally charged scene of this composition. For me, as a researcher, an archival tourist, considering the image of Sally in costume wearing a locket is similar to the experience of remembering an actress in a scene on stage. The drawing itself and the material objects depicted in it help to conjure the ghostly presence of Sally's body invoked in her letters. Sally's letter, then, can be seen as a kind of unworn costume, in 
that it is material, tangible evidence of a body that was once there, of Sally Siddons' embodied performance of writing.

In The Actor In Costume, Aoife Monks describes the presence of unworn costumes in the archives:

The costume in the archive stands as a testament to a performance that has gone but is stubbornly mute in its unwillingness to tell us 'what really happened ... The sadness and strangeness of unworn costumes may also be redolent of the losses in built in the performance event itself, in our desires as audience members for connection and presence, and the inevitable disappointment and dislocations that the performance brings. $(140,141)$

I think this is really useful in thinking about how we, as scholars, approach the performances of the past. Attention to material objects like jewelry, drawings, prints and letters reinforces both the "reality" of the flesh that was once there and the uncanny idea that what we have left is only a trace of what once was present. Love letters, or letters that foreground desire for connection or presence that is now absence, form a kind of fascinating paradigm for the unconscious mechanisms of archival research. That is our own longing to make the intangible tangible, and to bring the invisible center stage.

Unfortunately I can only visually map a 2-D view of the archival materials I have conjured here-juxtaposing those that are "real" with those that are substitutes for what the objects might have looked like. In narrating and partially visualizing my "virtual exhibition" I am going back to Griselda Pollock's assertion that that the feminist virtual museum "is about argued responses, grounded speculations, exploratory relations, that tell us new things about femininity, modernity and representation" (11). Pollock's charge encourages us to think about the visual, theatrical, and narrative relationship between archival materials in particular places at specific moments. Digital humanities projects and more specifically web-based scholarship allows us to bring questions of visual and theatrical culture more directly and immediately into our research. For example, Janine Barchas's amazing digital project What Jane Saw, which carefully recreates an exhibition of paintings By Sir Joshua Reynolds that Austen attended 1813. Barchas literally brings the archive to us by allowing viewers to experience the same juxtaposition of images as Austen did herself. ${ }^{8}$ Projects like What Jane Saw are significant and crucial to considering ways to stretch the boundaries of archival research, particularly in relation to women. Yet, in many ways, what excites me most about the possibilities for working in virtual media is also what makes me most concerned about it. I don't want to lose attention to the actual physical materials in the archive or to the experience of being an archival tourist in archival spaces. I also recognize that working with new technologies often requires wide-ranging institutional support and funding. Ultimately, I hope that what I have offered here is a potential strategy for thinking about methodologies for archival research that seek to connect materials from the past with our representations of them in the present, thus foregrounding our role in re-animating the secret life of archives. For, as Griselda Pollock reminds us, "Archives matter. What is included shapes forever 
what we think we were and hence what we might become. The absence of women's histories in world archives has defined a vision of the human on the pattern of a privileged masculinity. Humanity's self-definition requires a challenge to that vision" (12).

${ }^{1}$ For more on eighteenth-century actresses see Robyn Asleson's edited volumes, $A$ Passion for Performance: Sarah Siddons and Her Portraits (Los Angeles: The Paul J. Getty Museum, 1991) and Notorious Muse: The Actress in British Art and Culture, 1776-1812 (New Haven, CT: Yale University Press, 2003); Gill Perry, Spectacular Flirtations: Viewing the Actress in British Art and Theatre, 1768-1820. (New Haven CT: Yale University Press, 2008); and my own Fashioning Celebrity: Eighteenth-Century British Actresses and Strategies for Image Making (Ohio State UP, 2011).

2 This essay is adapted from a plenary lecture I presented at the Aphra Behn Society Conference on "Women, Fame, and Reputation" on October $24^{\text {th }} 2013$ in Tulsa, Oklahoma. The format is intended to mirror the accessibility of the plenary genre in narrative/printed form.

${ }^{3}$ See particularly Jacques Derrida, Archive Fever: A Freudian Impression, trans. Eric Prenowitz (Chicago and London: University of Chicago Press, 1995) and Michel Foucault, The Archeology of Knowledge and The Discourse on Language, trans. A. M Sheridan Smith (New York: Pantheon Books, 1972).

${ }^{4}$ I want to differentiate my use of the term "spectral matter" from Andrew Sofer's use of the term "dark matter" which he defines as "the invisible dimension of theatre that usually escapes detection, even though its effects are felt everywhere. If theatre necessarily traffics in corporeal stuff (bodies, fluids, gases, objects) it also conjures the incorporeal: offstage spaces and actions; absent or unrepresented characters; the narrated past; hallucination; blindness; obscenity; godhead; and so on. No less than physical objects and actors such invisible presences matter very much indeed, even if spectators, characters, and performers cannot put their hands on them" (330-31). Dark matter thus conjures what is not seen on stage - there is a clear and undeniable boundary between what spectators see and what they don't. Archival objects (both tangible and intangible) only represent a fraction of what was once visible in their original context. The term "spectral" seems more appropriate here, since archival materials represent both the fleshy present and traces of the absent past.

${ }^{5}$ This particular letter from Sally Siddons to Thomas Lawrence has an unusual archival history. It was not a part of the original sequence of letters chronicling the affair between Lawrence and the Siddons's sisters published by Oswald Knapp in 1905 in An Artist's Love Story. According to Lawrence's biographer, Douglas Goldring, this letter was part of Lawrence's private papers and not publically known until after the publication of Knapp's Artist's Love Story. Lady Priestley included the letter in an article, which 
appeared in the periodical, The Nineteenth Century and After, April 1905. Goldring explains that he is able to reproduce the letter "through the courtesy of Mr. John G. Nicholson," a descendent of Mr. Keightley, Lawrence's sole executor (137).

${ }^{6}$ John Boydell's Shakespeare Gallery, planned in 1786, featured images from Shakespeare commissioned by well-known artists. The paintings were also issued as engravings to a wide list of subscribers. The gallery flourished in its early years becoming a fashionable spot to see and be seen, but faltered in the 1790's when the support of French and continental clients waned in the aftermath of the French revolution. The gallery closed, the building sold and the works of art and engravings were dispensed of by lottery in 1805 . For more on the history of the gallery and its cultural impact see Christopher Rovee, “'Everybody's Shakespeare': Representative Genres and John Boydell's Winter's Tale.” In Studies in Romanticism, vol. 41, 2002. pp. 509-543.

${ }^{7}$ For more on the role of Sarah Siddons in this correspondence and on the significance of her varied maternal performances see my essay "Mommy Diva: The Divided Loyalties of Sarah Siddons" in Stage Mothers: Women, Work, and the Theatre 1660-1830 (forthcoming, Bucknell UP, 2014). Laura Engel and Elaine McGirr Eds.

${ }^{8}$ See also Katharine Kittredge's fantastic documentary video, "Chasing The Ghost of Melusina Trench: A film by Qina Liu in collaboration with Katharine Kittredge." http://scholarcommons.usf.edu/abo/vol3/iss1/5/.

\section{Works Cited}

Albinson, Cassandra. "Constructions of Desire." Thomas Lawrence: Regency Power and Brilliance. Ed. A. Cassandra Albinson, Peter Funnell and Lucy Peltz. New Haven: Yale UP, 2010. Print.

Braudy, Leo. "Knowing the Performer from the Performance: Fame, Celebrity, and Literary Studies.” PMLA 126.4 (2011): 1070-1075. Print.

Gilli Bush-Bailey. "Re-Enactment." The Cambridge Companion to Theatre History. Ed. David Wiles and Christine Dymkowski. Cambridge: Cambridge UP, 2013. 281-298. Print.

Cook, Terry and Joan M. Schwartz. "Archives, Records, and Power: From (Postmodern) Theory to (Archival) Performance. Archival Science 2 (2002): 171-185. Print.

Davis-Fisch, Heather. Loss and Cultural Remains in Performance: The Ghosts in the Franklin Expedition. New York: Palgrave, 2012. Print.

Endsor, Tim. "Performing tourism, staging tourism: (Re) producing tourist space and 
practice.” Tourist Studies 1.1 (2001): 59-81. Print.

Foucault, Michel. The Archeology of Knowledge and The Discourse on Language, Trans. A. M Sheridan Smith. New York: Pantheon Books, 1972. Print.

Gallagher, Catherine. Nobody's Story: The Vanishing Acts of Women Writers in theMarket Place: 1670-1820. Berkeley: U of California P, 1995. Print.

Goldring, Douglas. Regency Portrait Painter: The Life of Sir Thomas Lawrence. London: Macdonald, 1951. Print.

Oswald Knapp. An Artist's Love Story. London: G. Allen, 1905. Print.

Manoff, Marlene. "Theories of the Archives Across Disciplines." Portal: Libraries and the Academy 4.1 (2004): 9-25. Print.

Aoife Monks. The Actor in Costume. New York and London: Palgrave, 2010. Print.

Nussbaum, Felicity A. Rival Queens: Actresses, Performance and the Eighteenth-Century British Theater. Philadelphia: U of Pennsylvania P, 2010. Print.

Osborne, Thomas. "The Ordinariness of the Archive." History of the Human Sciences 12.2 (1999): 51-64. Print.

Pointon, Marcia. Brilliant Effects: A Cultural History of Gem Stones and Jewellery. New Haven: Yale UP, 2010. Print.

Pollock, Griselda. Encounters in the Virtual Feminist Museum: Time, Space and the Archive. London: Routledge, 2007. Print.

Roach, Joseph. It. Ann Arbor: U of Michigan P, 2007. Print.

Shakespeare, William. As You Like It. Ed. Agnes Latham. Arden Shakespeare Series. London: Thomas Nelson and Sons Ltd. 1997.

Sofer, Andrew. "Spectral Readings.” Theatre Journal, 64 (2012): 323-336.

Steedman, Carolyn. Dust: The Archives and Cultural History. New Brunswick: Rutgers UP, 2002. Print.

Taylor, Diana. The Archive and the Repertoire: Performing Cultural Memory in the 
Engel: The Secret Life of Archives

Americas. Durham: Duke UP, 2003. Print. 